\title{
SELF-DIRECTED FEEDBACK: AN ATTEMPT TOWARDS LEARNER AUTONOMY IN WRITING
}

\author{
Tsara Desiana Akmilia \\ English Education Department, Indonesia University of Education, Indonesia \\ E-mail: tsaradesiana@gmail.com \\ Pupung Purnawarman \\ English Education Department, Indonesia University of Education, Indonesia \\ E-mail: ppurnawarman@gmail.com \\ Rojab Siti Rodliyah \\ English Education Department, Indonesia University of Education, Indonesia \\ E-mail: rojab.siti@gmail.com
}

APA Citation: Akmilia, T. D., Purnawarman, P. \& Rodliyah, R. S. (2015). Self-directed feedback: An attempt towards learner autonomy in writing. Indonesian EFL Journal, 1(1), 48-57

Published: 01-01-2015

\begin{abstract}
This paper aims to investigate the application of self-directed feedback in a writing classroom in terms of how it may affect their skills in writing and the students' response to it. The study was conducted in one of public high schools in Bandung, taking nine students of a science class as the participants. It employs a case study which is using interview and document analysis as the data collection techniques. The findings show that after the inclusion of self-directed feedback in four drafts, the students managed to have a progress in terms of organization, vocabulary, mechanics, and grammar in the process of writing a report text. The awareness of their own progress also indicates a trait of an autonomous learner. Most of the students saw self-directed feedback as a worthy technique to be used again in the subsequent lessons. As a conclusion, self-directed feedback is proven applicable in the writing classrooms as it functions as a step in making students acquire strategies of learning autonomy. For further research, it is suggested that self-directed feedback is included in a set of a self-monitoring strategy rather than one exclusive technique.
\end{abstract}

Keywords: self-directed feedback, writing, learner autonomy

\section{INTRODUCTION}

Within the context of EFL classrooms, it is quite common to find classes with a high number of students. For teachers who need to face about 40 students in one class-the condition that is happening widely in Indonesia-the job could be overwhelming. Furthermore, in the writing classes when the process of editing and re-drafting is highly endorsed, this condition is not beneficial. It is possible that teachers skip the process for practicality reasons. When we talk about writing classes in particular, to be able to facilitate students to write better, one of the ways is to include feedback for revision before writing assignment is collected. According to Susanti (2013), in Indonesia it is common to have feedback given by teachers seeing that "teachers are the people who are educated to teach and correct their students' assignments while students are people who have to receive the corrections and obey every instruction from their teachers" (Susanti, 2013, p 1-2). However, to rely on teacher feedback in the aforementioned condition may result in no feedback at all at worst. Self-directed feedback, which was chosen as an independent variable in the study, could be one of the solutions. The technique is carrying the value of learner autonomy, as stated by Cresswell (2000, p. 235) that "The student self-monitoring technique increases autonomy in the learning of writing by giving 
learners control over the initiation of feedback." This way, the teacher does not need to shoulder the burden of providing feedback alone.

At last, considering the importance of having better practice in teaching writing in large classrooms through autonomous learning, together with the fact that selfdirected feedback may create the opportunities to raise students' awareness on writing, the study sought to design a study connecting both of the components to be put into practice in an EFL classroom.

According to Lin (2009, p. 61), the aim of self-directed feedback is "to raise awareness of the important elements and conventions in the process of composing essays, and helps students to acquire them in order to become independent and competent writers." It is also recognized as self-feedback (see Saito, 1994; Zhang, 1995; Hattie and Timperley, 2007) or self-provided feedback (Lamberg, 1980), in which each term refers to the same definition - a feedback which is formulated by the students themselves.

In the process of self-feedback in writing, the writer is placed in the reader's role. According to Rijlaarsdam and van den Bergh (2004), this is beneficial since the students will be exposed to text problems, or at least to practice their reading skills. It was further stated that the experience replicates the difficulties in the writing process, such as incorporating reader perspective in the composing, dealing with reader's expectation, how to guide the readers to its writing, as well as checking the final text based on readers' understanding (Rijlaarsdam and van den Bergh, 2004).

Another support coming from Ferris (2003), who stated that in writing, it is important to arm students with strategy training to avoid errors and self-edit their work. That being said, it can be inferred that students' role in regulating themselves in the process of writing is vital and inevitable. This can be realized through self-directed feedback.

In terms of its significance to revision, Paulus (as cited in Ferris, 2003) in his study found that in terms of influence in the whole revising process through three drafting stages, the "self/other" category outnumbered peer and teacher feedback. Ferris (2003) then concluded that from the findings, it can be argued that even rereading and rewriting that does not involve peer or teacher may open an opportunity of students having both substantive changes and a better quality in writing.

Saito's (1994) work focused on selffeedback in the form of self-correction in which she categorized self-feedback as one of the non-teacher feedback. Her study, however, does not investigate as to what extent the students went with their own selfcorrection. In her paper, Saito (1994) mentioned that "students may be able to use such techniques to develop their communicative competence, skills to criticize their own writing by themselves, and to cope with errors without depending on a teacher" (Saito, 1994, p. 65).

A widely used definition of learner autonomy came from Holec (as cited in Kumaravadivelu, 2003), who defined it as "the ability to take charge of one's own learning." Another view came from Benson (2006), who mentioned autonomy in learning as a condition when people take more control over their learning inside and outside the classroom.

Although the ultimate goal in realizing learner autonomy is to have learners who does not require teacher in their learning (Lamb, 2008), this does not necessarily mean that the role of teacher in the classroom is vanished at all. According to Lamb (2008), the kind of learning expected is one that does not take place independently of the teacher, but one in which the teacher shifts his/her focus in teaching to support the learners' development in autonomy. This can be realized by teachers introducing the learners into the strategies to become autonomous learners.

An autonomous learner, then, is not a learner who does not take any kind of support into account. Moore (1972) characterizes autonomous learners as the ones who still turn to teacher to assist them in formulating problems, collecting information, and evaluating their progress. That is why the self-directed feedback is suggested not to be applied in an exclusion from the other types of feedback, but rather 
as a complement to teacher and peer

feedback as students are releasing

themselves from too much dependency to others.

According to Cresswell (2000), autonomy in the learning of writing can be increased through self-monitoring technique. This is in line with the process approach to writing that is also characterized with the presence of help for the students to be aware of their own writing process (Shih, as stated in Brown, 2001). This implies that it is not the teachers who should be the main actor in the process of writing, but the students. Therefore, to include learner autonomy in the course of writing is a necessity since the students also need to be aware that they are the one who give the direction to the progress of their own writing. Furthermore, self-feedback in this matter promotes the exact same thing, when the learners are acquired to be the first person to check on their own writing and if possible make corrections for the mistakes. The importance for having the self-monitoring technique is also acknowledged by Dickinson (as stated in Cresswell, 2000), who argued that it offers a sense of self-direction, which refers to a process enabling learners to choose their learning focus as well as a recognition to their own responsibility. The value of responsibility is also what is supported in the learner autonomy.

\section{METHOD}

The method used in this study is qualitative. It also employed the case study as it was considered the best method to answer the research questions.

The data were taken in a qualitative form through interviews and document analysis. This study was conducted in one of public Senior High Schools in Bandung. The participants were 9 eleventh graders of a science class. Throughout the study, the students were asked to write a report text under six topics: chocolate, animation, greenhouse effect, bee, cactus, and microscope. The first meeting was used to have a recap about report text only to remind them about the generic structure, as well as the nature of report text. The researcher, who acted as a teacher in this meeting, did this on purpose since the topic of report text had been discussed in the class with their teacher. After that, still in that meeting, they chose one topic out of six, and they were expected to make their first draft before the next meeting. At the second meeting, as the students brought their first drafts to the class, the researcher asked them to formulate a self-directed feedback for their own texts. The researcher informed them about several aspects that they could work on: generic structure, punctuation, spelling, vocabulary, and grammar. In the next two meetings, they continued to work on their feedback and revise the text. They had the chance to revise their writing until the fourth draft. The students were asked to work on their texts from September 9, 2013 to September 23, 2013 or two weeks in total to finish until the final draft. After that, they were asked to collect all of their drafts-from the first to the fourth-to be analyzed. Their texts were analyzed only in terms of the organization, mechanics, grammar, and vocabulary (adapted from the types of errors described by Thornbury, as cited in Hernàndez, 2011). The researcher looked at their errors on those parts and their attempt to fix them. If, for example, the students had mistakes in grammar in their first draft, then the researcher would look at the subsequent drafts (second, third, and fourth) to see whether changes were made in the place where the mistakes were seen before. If they made correct changes, then it would be regarded as a progress in grammar. Another scenario would be the students made changes but they happened to be incorrect. In that case, the progress was not present. This also means that even if the students happened to be marking their mistakes by circling or underlining it, as long as the correct changes were not seen in the next drafts, then they would not be counted as a progress. The analogy applied to the other three aspects mentioned before.

In-depth interviews were conducted after the texts were submitted. Five guideline questions were used to help giving an insight on what the students' response towards the activity is. Question number five works as a confirmation on the findings derived from the document analysis. The interviews were 
conducted individually in which the students are called one by one to have an informal talk with the researcher. An informal setting is considered necessary in order to provide an ease for the interviewee, so that real and authentic answers can be derived. It was also carried out in bahasa Indonesia to provide comfort for the interviewee during the conversation. The interviews were transcribed and later analyzed using the related literature.

\section{FINDINGS AND DISCUSSION}

The findings show that students had progress in their writing skills. Most of them also responded positively to the application of self-feedback, even though the presence of negative response is also unavoidable. The elaboration is as follows.

\section{Students' progress in their writing skills}

In regards to the students' writing skill, the findings show that they were able to detect errors in their writing and they were also progressing in some aspects of the writing skills. From the first until the final draft, all students made progress in organization, mechanics, grammar, and vocabulary. It should be bear in mind, though, that not every student made progress in all four aspects-some only improved in three or two aspects only. The details will be explained in the following points.

\section{Organization}

In this study, a student is considered having a mistake in organization if they did not use the structure in composing their text, and is said as progressing if they changed the incorrect structure to the one described by Macken-Horarik (2002). Out of nine students, only two students did not follow the structure in organizing their ideas. The rest of the subjects had used the structure from the very first draft, therefore their texts will not be analyzed in this part. From the two students who made mistakes in organization, only one had a progress.

The first student is Student 8, who progresses during the time of his writing. He did not follow the generic structure in his first draft, but finally managed to organize his ideas so that it fits to the generic structure in the information report text only in the last draft.

Awareness in organization, as was stated by Starkey (2004), lets writers see how developing ideas suit a framework. Sundem and Pikiewicz (2006) mentioned that logical framework in writing shows careful planning and foresight. Therefore, when students are aware of their issue in organization and revise it, it means that they made an attempt to guide themselves to make a better writing in terms of developing the ideas. Other than that, having a better organization in ideas represents their awareness of having a careful planning in writing.

On the other hand, another student, Student 6, did not make any revision regarding her mistakes in organization. The ideas did not follow the structure of an information report text because the text does not include qualities and functions of the topic she got. According to the interview, she stated that she did not find much problem in her text.

Looking at the characteristic, this can be categorized as a mistake that occurs continuously without any effort to correct it, which is defined as "the use of a linguistic item in a way which a fluent or native speaker regards as showing faulty or incomplete learning" (Richards and Schmidt, 2002 , p. 184). From Student 6's case, it shows that she either has not acquired knowledge on organization or is still having an incomplete comprehension on it.

From the two cases (Student 8's and Student 6's), it can be inferred that the selfregulatory proficiency is needed in order to make self-feedback work. This is shown from Student 8's awareness to make a careful planning of his writing after the self-feedback. Other than that, it is also important for students to acquire the knowledge about the text. This is shown from Student 6's case.

\section{Mechanics}

Mechanics had been one of the things that the students had focused on in the process of self-feedback. Gentry, McNeal and Wallace-Nesler (2012) mentioned that students need to have control over the use of capitalization, punctuation and spelling of their own writings. 
First, four students encountered problems in terms of spelling. All of them were conscious of the misspelling of the words they used and changed them to the correct form. The mistakes and corrections for the four students hold the similar pattern-they missed one letter or added another letter. From the first glance, the readers will recognize the word they intended to say, so the effect to meaning is not major.

Starkey (2004) mentioned that knowledge of the basic rules will help writers in giving a positive impression for readers. Fry (2003) stated that glaring mistakes in spelling will make an impression of a careless and ignorant writer. By discovering mistakes in spelling during the self-directed feedback, it means that they get the impression of their own writing. Furthermore, by correcting it, they have made an attempt to provide a better impression to their intended readers.

Second, out of nine students, only two students have issues in terms of punctuation. The indicator of mistake in punctuation is when they do not use punctuation marks according to its functions. The two students who made mistakes in punctuation are able to detect their own errors, and have successfully corrected them in their revised drafts. The issues are related to the use of period and comma.

According to Starkey (2004), a writer can convey the voice of his/her writing more directly through proper punctuation. The effective communication can be ensured by correct punctuation since it functions to signal the relationship between words or ideas as well as marking out the boundaries of meaning (Perk and Coyle, 2005). The correction in students' punctuation, then, shows how they tried to voice their writing better, in terms of making long sentences to be the more direct ones. Furthermore, a correction in punctuation also helps in making a positive impression to the writing. This means that they, as a writer, have become conscious about the impression that reader may perceive from their writing.

Third, out of nine students, only two students made mistakes in terms of capitalization. One student made mistake in mentioning some proper nouns, and the other did not put capital letter for the first words of every sentence. Langosch (1999) stated that the most important consideration in capitalization is to be consistent leaving a word with capital in a sentence and capitalizing it in another would create problem for the readers. Kemper, Meyer, Van Ryk and Sebranek (2011) mentioned that becoming a reader and writer would be of help in learning the unexpected changes in capitalization. As was seen in the students' writings, it is true that the inconsistency happens. However, they also solved it by rereading the text in the process of having a self-directed feedback.

Furthermore, for students to be aware of the capitalization enables them to apply some writing strategies for proofreading and self-correction (Gentry et al., 2012). As the students in this research became more aware of the capitalization, this also means that through the process of self-directed feedback, the students have applied the strategies for proofreading as well as self-correction which will be beneficial for their writing in the future.

\section{Grammar}

Even though the students have different level of proficiency, seven out of nine students are able to correct their own errors. This is limited only to the use of subject verb agreement, plural/singular nouns, and modal verbs. All of them circled or underlined their mistakes and revised them in the subsequent drafts.

In general, the importance of having perfection in grammatical form was admitted by Brown (2001) as writing resulted in permanence. Therefore, he stated that a focus in grammar will be more effective when it is taught for the writing skills rather than speaking, listening, or reading (Brown, 2001). From what can be seen in the students' progress in grammar which does not cover all aspects, it shows that it still does not ensure a full accuracy in students' writing. Therefore, this progress is not enough for the text to be considered as an acceptable report text since it is included to formal text that demands accuracy in grammar. However, for teaching purposes, 
the student's inability to look at the other aspects of grammar shows their level of proficiency, and it can play a significant role in informing teachers of what to focus on in the following grammar teaching.

Since teacher should not force too much grammar on beginning level learners (Brown, 2001), this finding can benefit teachers to only focus on grammar forms that the students had failed to correct but are already aware of, providing an information that the student needs assistance in those parts. According to Corder (as cited in Erdogan, 2005), knowing students' error can notify teachers about the learning gap left between the learning goal and students' progress, showing teachers the point that demands further attention. On the other hand, the fact that some of the students are able to correct their own grammar mistakes supports the policy of not focusing too much on grammar as it may disturb fluency (Brown, 2001). The writing lesson still needs to maximize student's self-correction instead of teachers spending more time in giving grammar correction to their students (Brown, 2001). This was based on the justification that as the learners starting to perform by his or her own, a support can be gradually removed in order to support a step to autonomous learning (Zimmerman, 1990).

\section{Vocabulary}

In terms of vocabulary, the problem found from the students is that they include technical terms in their text, however they still use the Indonesian terms. From their drafts, five students still mistook the terms in the first drafts but then corrected them in the following drafts.

It is a common sense that in writing, a demand in vocabulary is considerably higher than speaking. Especially when writing a report text, whose purpose is "to describe a characteristic of something" (Palmer, 2010), the writer is asked to find a richer vocabulary in order to describe the topic well. This can be difficult for any writer. However, Brown (2001) stated that the richness of English vocabulary will in turn be an advantage for good writers as they learn from it. One of the students initially gave up with her limitation in vocabulary, but after given more time to re-check her writing and revise it, she eventually found the appropriate technical terms suit to the meaning she intended. She, therefore, has possessed the characteristic of a good writer.

Other than the results presented above, another finding shows the way the students use the self-directed feedback to improve their writing. From the interview, most of the students said that they were focusing on one or two particular matter whenever they are working on a draft. As an example, student 6 when was asked about what she was working on the first and following drafts answered:

$$
\begin{aligned}
& \text {...dibenerinnya... ya itu, grammarnya sih... terus } \\
& \text { kalo misalnya vocabnya kerasa aneh, baru diganti. } \\
& \text { Yang secondnya, masih grammar... sampe third, } \\
& \text { third.. nah, waktu third teh ini... ngebaca lagi. } \\
& \text { Nyambung nggak ini ceritanya... (I corrected my } \\
& \text { writing in.. well, the grammar.. and then if the } \\
& \text { vocabularies felt weird, I changed it. [In] the } \\
& \text { second [draft], [I still] fixed the grammar.. until } \\
& \text { the third, well.. I read it again [if] the topic is } \\
& \text { connected to each other...) }
\end{aligned}
$$

Some other students also give different focus in working on their feedback, such as punctuation or spelling. This finding shows that, in the study, self-feedback shares the traits of teacher corrective feedback that include focused and unfocused ones. This was based on the definition given by Ferris (2011) who stated that focused feedback essentially means targeting correction to specific error types or patterns while unfocused feedback refers to correcting any and all problems observed in text without a preconceived feedback approach in mind. By focusing the direction of the feedback, this means that the students have conceived what they want to work on first in mind. As the students monitor themselves, Dickinson (as stated in Cresswell, 2000) stated that they can also self-direct themselves when they choose their learning focus as well as recognizing their own responsibility. Taking control of feedback allows learners to attend to important items in the context so that they can have either an informed correction or positive feedback in order to support acquisition and set up the items in their productive inventory (Cresswell, 2000). Therefore, by having self-feedback, the 
process supports their language acquisition from what they attend to while looking at their own texts. The responsibility that they shoulder also enables them to choose their learning focus.

\section{Students' Response}

In general, students' response to the application of self feedback in their process of writing is mostly positive. Still, the negative drawbacks that the students feel during the course are still present.

\section{Positive response}

From the interview, the students think that first, self-feedback enables them to look at their own progress in writing. Some students mentioned that it is beneficial as they can be aware of what to improve. Secondly, the students also think that selffeedback is important in the writing process. They think that it is important to get rid of their mistakes that are resulted from carelessness, and they also think that it is important so that the teacher would look at their progress thoroughly. Thirdly, the students perceived self-feedback as an alternative activity in writing, since they only experienced limited techniques that teachers apply in the writing class. Lastly, the students also think that self-feedback changes their perspective to writing and it makes the process of writing easier. The discussion is as follows.

Out of nine students, four in the study mentioned that self-directed feedback can be utilized to track their own progress in writing. For instance, Student 2 in the interview mentioned how she thinks that self-feedback enables her to look at her own writing, enlightens her about the things she needs to improve. When the interviewer asked her about what she thinks about the self-feedback, her answer was as follows:

\footnotetext{
... nggak malesin. Malah bikin seneng, jadi kan kita tuh ngeliat dari tulisan kita sendiri. Kesalahan kita tuh apa.. Ternyata waktu itu, Fika tuh banyak banget salahnya.. ([It was] not boring. It makes me feel happy instead. As we look at our own writing.. What our mistakes are.. Apparently at that time, I had so many mistakes [in my writing]..)
}

As was stated by Narayanan et al., (2008), one of the factors that may be dependent to the successful second language acquisition is on the learners' views of the learning situation. This positive attitude to self-directed feedback proves that this is also what makes it works for them. Moreover, by having students to monitor themselves gives two benefits to learners--they are able choose their learning focus and a recognition to their own responsibility (Dickinson, as stated in Cresswell, 2000).

From the interview, all of the students also think that self-directed feedback should be included in the subsequent writing lessons. Student 2 answered that she needed it because she was a rather careless person, while student 6 highlighted that she wanted the teacher to look at her progress rather than just the final product. This proved that self-feedback can be used to clear up mistakes, as mistakes was stated as a result of carelessness (Richard and Schmidt, 2002). On the other hand, another statement from student 6 represented students' demand to use process approach in writing, since in the process approach, the process is also at least as important as the product (Harmer, 2007).

Other than being helpful, three students out of nine felt that the activity was refreshing and more beneficial for their further progress.

From the interview, one student-even though this is the first time for her to experience self-feedback in class-had already welcomed the activity and prefer it to the other activities she usually did in her previous classes. Ideally, a writing lesson according to process approach would include all stages of writing starting from pre-writing to producing the final version of students' work, even though it practically takes a longer time (Harmer, 2007). The application of self-directed feedback in the writing classroom, then, can encourage more stages in writing to be experienced by the students.

Another response coming from the students is even though the application of self-feedback in this study lasted for only two weeks, but two students confessed that it was enough to make them feel more comfortable with writing. 
One of the students, Student 6 , admitted that she had been taking a private course at home. During the self-directed feedback process, she could not meet her private teacher, and so that is why she did it all by herself. She admitted that it was unexpectedly easier than what she thought it would, and she got more enthusiastic to finish her writing. It shows that the student has gained the ability not to be dependent to external constraints, which shows a trait of self-regulation. Self-regulation, which is one of the terms related to learning autonomy, initially derived from the interest in selfcontrol that refers to an ability to have a control in one own's actions without immediate external constraints (Thoresen and Mahoney, as cited in Zimmerman, 1990).

From the interview, besides the affective benefits, it turned out that six students out of nine also perceived self-feedback as an activity that eases them in making the report text. Student 2 reported that the writing process became easier with self-feedback because she was given more time until the final draft to revise her own writing, and therefore made her be more independent. She mentioned that writing became easier because they were given more time and she was given the freedom to choose the direction of her own writing. According to Rubin and Thompson (as cited in Brown, 2001), one of the characteristics of good language learners is a learner who is able to take charge of their own learning, by finding his/her own way in completing a task. Brown (2001) mentioned that "the more your classroom activity can model the behavior exhibited by successful language learners, the better and more efficient your students will be, especially in developing their own autonomy as learners" (p. 210). Therefore, self-directed feedback can encourage one trait approaching learner anatomy as it enables the student to monitor his/her own progress.

\section{Negative response}

Albeit most of the students were happy with having the self-directed feedback, some negative responses were also found from the interview. Some think that selfdirected feedback resulted in a boredom, a trauma to write more, and to some extent it makes writing gets harder.

For example, student 7 thought that working on the same text over and over again resulted in a boredom. From her statement in the interview, she actually pointed out on how keep checking for the exact same text is boring for her. However, in the questions after that, she mentioned that the technique is still necessary for writing. She only suggested the decrease in the amount of drafts:

$$
\begin{aligned}
& \text {... Perlu... Cuma kalo kata aku mah nggak usah } \\
& \text { sampe empat kali gitu, miss... jadi, gimana dua } \\
& \text { kali gitu... nggak usah banyak-banyak, nanti } \\
& \text { bosen... ([It is] necessary... I just think that it } \\
& \text { does not have to be four [drafts], miss... Like, } \\
& \text { only twice... It doesn't have to be that much, it's } \\
& \text { going to be boring...) }
\end{aligned}
$$

The mere reason the student gave for the boredom was because she thought she only got little to correct. This was pointed out by Starkey (2004) who mentioned that many writers skip the re-checking process of writing because they feel intimated by the thought of reworking it, clinging to a hope that their writing is "good enough". He further mentioned that "there is no excuse for submitting an essay that is not the very best writing you are capable of" (Starkey, 2004 , p. 55). The student, then, were still in need to acknowledge the principle in order to see that in attempt to make the best of her writing require more time in revising. This factor, unfortunately, was not the one that seems to be able to be promoted by selfdirected feedback in this research.

On the other hand, Student 4 felt that from having self-directed feedback, he did not want to write more in the future. From his statement in the interview, self-directed feedback for him lessens his confidence. He felt that no matter how much he fixed it, he still could not make things right. Harmer (2007) described this phenomenon as a result of a less enthusiastic learner who suffered from a low self-esteem. He stated that it is unlikely for these students to continue studying on their own after the course had finished (Harmer, 2007). It is the evidence that students' low self-esteem matters in performing self-directed feedback. 
More than level of proficiency, students' readiness to accept their own mistakes is more important in ensuring students' learning autonomy in the long run.

Lastly, despite the fact that six students actually felt that writing becomes easier with self-directed feedback, two students highlighted how it made writing get even harder. From the interview, the students seemed to still worry a lot about making mistakes in his writing. However, he did not mention that it was directly caused by the self-directed feedback. He pointed out the possibility of keep having mistakes until the last draft. This is caused by the lack of confidence and low self-esteem that makes the student not dare to take risk in learning. Brown (2001) mentioned that when learners are already able to cope with their own ego fragility and build a firm belief that they can do it, then they are ready to take the necessary risks. This finding then, shows how risk-taking is important as a prerequisite of the application of self-directed feedback.

\section{CONCLUSION}

Throughout the research, three conclusions can be derived. Firstly, regarding the presence of self-directed feedback, even though it is not quite common in the teaching practice-according to students' experiences, that is - the demand of it to be applied was there. In the findings, it was proven that it gives benefits for students' writing skills and the students felt it as well.

Secondly, in relation to the ability of self-directed feedback in promoting the value of learner autonomy, from the findings it can be seen that the students are able to witness their own progress. To be able to see it brings the sense of responsibility, as well as an encouragement to direct their goals in learning.

Lastly, it can be concluded that selfdirected feedback can spare teacher's responsibility in their students' progress. In the Indonesian context when classes generally consist of 30 to 45 students, and teachers' workload to teach more than three classes in a week, feedback in writing sounds impractical. By having self-directed feedback, the teachers can focus on the things that the students do not acquire yet, and the students will still have a progress in learning even without much help from the teacher.

\section{References}

Benson, P. (2007). Autonomy in language teaching and learning. Language Teaching, 40(1), 21-40.

Brown, H. D. (2001). Teaching by principles: An interactive approach to language pedagogy, second edition. New York: Addison Wesley Longman, Inc.

Cresswell, A. (2000). Self-monitoring in student writing: Developing learner responsibility. ELT Journal, 54(3), 235-244.

Erdoğan, V. (2005). Contribution of error analysis to foreign language teaching. Mersin University Journal of the Faculty of Education, 1(2), 261-270.

Ferris, D. R. (2003). Response to student writing: Implication for second language students. Mahwah: Lawrence Erlbaum Associates.

Ferris, D. R. (2011). Treatment of error in second language student writing, second edition. University of Michigan Press.

Fry, Ron. (2003). Last minute term papers. Frankin Lakes: The Career Press, Inc.

Gentry, R., McNeal, J. \& Wallace-Nesler, V. (2012). Getting to the core of writing: Essential lessons for every second grade student. Huntington Beach: Shell Education.

Harmer, J. (2007). The practice of english language teaching. Harlow: Pearson Education Limited.

Hattie, J. \& Timperley H. (2007). The power of feedback. Review of Educational Research, 77(1), 81-112. doi: $10.3102 / 003465430298487$

Hernàndez, M. S. (2011). Raising student awareness about grammatical and lexical errors via email. Revista de Lenguas Modernas No 14, 263-281.

Kemper, D., Meyer, V., Van Rys, J., \& Sebranek, P. (2011). Fusion: Integrated reading and writing, Book 1, $1^{\text {st }}$ ed. Boston: Wadsworth.

Kumaravadivelu, B. (2003). Beyond methods: Macrostrategies for language teaching. New Haven: Yale University Press.

Lamb, T. (2008). Learner autonomy and teacher autonomy: Synthesizing an agenda. In Lamb, T. \& Reinders, H. (Eds.), Learner and teacher autonomy: Concepts, realities, and responses (pp. 269-284). Amsterdam: John Benjamins Publishing Company.

Lamberg, W. 1980. Self-provided and peer-provided feedback. College Composition and Communication, 31(1), 63-69.

Langosch, S. L. (1999). Writing American style: An ESL/EFL handbook. Hauppauge: Barron's Educational Series, Inc.

Macken-Horarik, M . (2002). 'Something to shoot for': A systemic functional approach to teaching genre in secondary school science. In A M Johns (Ed.), Genres in the classroom: Applying theory and research to practice (pp. 17-42). Mahwah, NJ: Lawrence Elbaum Associates, Inc.

Moore, M. G. (1972). Learner autonomy: The second dimension of independent learning. Convergence, 5(2), 76-88. 
Narayanan, R., Nair, N. J., \& Iyyappan, S. (2008). Some factors affecting English learning at tertiary level. Iranian Journal of Language Studies (IJLS), 2(4), 485-512.

Palmer, S. (2010). How to teach writing across curriculum: Ages 8-14. Taylor \& Francis e-Library.

Richards, J. C. \& Schmidt, R. (2002). Longman dictionary of language teaching and applied linguistics. London: Longman.

Rijlaarsdam, G., \& Van den Bergh, H. (2004). Effective learning and teaching of writing. In G. Rijlaarsdam (Series Ed.), G. Rijlaarsdam, H. Van den Berg, \& M. Coizjan (Vol. Eds.), Studies in writing. Vol. 14, Effective learning and teaching of writing, $2^{\text {nd }}$ Edition (pp. 1-16). Boston: Kluwer Academic Publishers.

Saito, H. (1994). Teachers' practices and students' preferences for feedback on second language writing: A case study of adult ESL learners. TESL
Canada Journal/Revue TESL Du Canada, 11(2), 64-68.

Starkey, L. (2004). How to Write Great Essays. New York: LearningExpress.

Susanti, R. (2013). Students'perceptions Towards The Effective Feedback Practices in The Large EFL Writing Class Based On Participants, Gender, And English Proficiency Level (Doctoral dissertation, Indiana University of Pennsylvania). Retrieved from

https://dspace.iup.edu/bitstream/handle/2069/ 2002/Rini\%20Susanti\%20(Thesis).pdf?sequence $=1$

Zhang, S. (1995). Reexamining the affective advantage of peer feedback in the ESL writing class. Journal of Second Language Writing, 4(3), 209-222.

Zimmerman, B. J. (1990). A social cognitive view of selfregulated academic learning. Journal of Educational Psychology, 81(3), 329-339. 